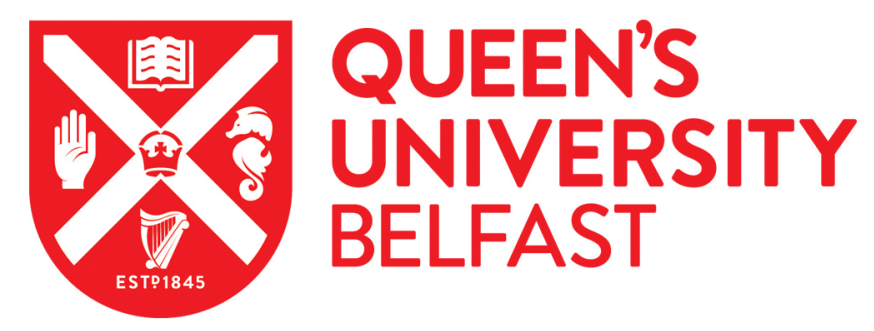

\title{
Russia - One Hundred Years After Revolution
}

Titov, A. (2017). Russia - One Hundred Years After Revolution. Political Insight, 8(3), 12-15.

https://doi.org/10.1177/2041905817744622

\section{Published in:}

Political Insight

\section{Document Version:}

Peer reviewed version

Queen's University Belfast - Research Portal:

Link to publication record in Queen's University Belfast Research Portal

\section{Publisher rights}

(c) 2017 The Author. This work is made available online in accordance with the publisher's policies. Please refer to any applicable terms of use of the publisher.

\section{General rights}

Copyright for the publications made accessible via the Queen's University Belfast Research Portal is retained by the author(s) and / or other copyright owners and it is a condition of accessing these publications that users recognise and abide by the legal requirements associated with these rights.

Take down policy

The Research Portal is Queen's institutional repository that provides access to Queen's research output. Every effort has been made to ensure that content in the Research Portal does not infringe any person's rights, or applicable UK laws. If you discover content in the Research Portal that you believe breaches copyright or violates any law, please contact openaccess@qub.ac.uk. 


\section{Russia - One Hundred Years After Revolution \\ Political Insight, Volume: 8 issue: 3 , page(s): 12-15 \\ Alexander Titov, Queen's University Belfast}

The revolutions of 1917 transformed Russia forever. A century on, Russia again finds itself at a crossroads with President Putin set for another term in office but domestic economic and political challenges mounting.

In March 2018, Russia will hold presidential elections. The incumbent, Vladimir Putin, is expected to run and win. The Russian constitution, adopted in 1993 after a violent clash with supporters of the old Soviet parliament, gives an extraordinary amount of power to the president's office. Putin has consolidated even more informal power during his 17 years in office. Big business, mass media and rival political parties have all been brought to heel, while power and material resources have been carved up amongst people loyal to him.

All the while, Vladimir Putin has remained one of the most popular leaders in Russian history. In large part this has been due to the fact that his policies, from cutting oligarchs down to size, to standing up to the West to assert Russia's interests in Ukraine, have struck a chord with most Russians, who believe in the importance of maintaining a strong state domestically and the need to project the status of a great power internationally.

\section{Domestic concerns}

The current political system is centred around Putin, largely deriving its very legitimacy from his charismatic appeal. Yet, according to the constitution, 2018 will be the last time Putin, who celebrated his 65th birthday in October 2017, can run for president. Although Putin has in the past preserved his power by moving out of the president's office, as he did during Medvedev's presidency in 20082012, the question of succession is likely to dominate Putin's last official term as president.

Putin's final presidential campaign comes at a potentially difficult moment, dominated by economic, political and foreign policy challenges. While part of 
Putin's popularity in his first two terms as president (2000-2008) was based on an unprecedented growth in living standards, the Russian economy stalled after the financial crisis of 2008. Slow economic growth went into outright recession after 2014 under the double pressure of Western sanctions imposed because of the Ukraine crisis and a collapse in the price of oil, which accounts for around half of Russia's state revenues. Real incomes are well below pre-crisis levels.

These pressures call into question the durability of Putin's rule. The system needs to preserve the right balance between stability and development, particularly because the economic performance has been disappointing. Oil and an economic recovery, based on realignment of the remains of the Soviet economy towards a more consumer-oriented model, are no longer sufficient to generate sufficient growth. This raises the possibility of increasing social discontent and may undermine national security against a backdrop of a continuing standoff with the West.

\section{Presidential elections}

Although Putin is expected to win in March 2018, there are important questions about the upcoming presidential elections. How many will actually vote? What vote share will go to Putin? In an electoral system modelled on the French, Putin has to get at least 50 per cent in the first round to avoid a run-off, but ideally would like to increase his share of the vote from the last elections in 2012, when he secured 63 per cent vote share on a 65 per cent turnout. There was talk of 70/70, that is 70 per cent of votes with 70 per cent turnout, but recently the Presidential Administration, who is responsible for elections, have dampened such expectations.

The relative legitimacy of elections will also depend on the availability of other candidates and the fair counting of votes. After the parliamentary elections in 2011 , the perception of widespread electoral fraud led to mass protests across Russia that shook the regime and prompted a series of experiments with the political system. For example, by allowing limited participation by the radical opposition in local elections. Alexey Navalny, a prominent critic in chief of Putin's regime, subsequently contested the Moscow mayoral elections in 2013. 
However, the electoral system remains tightly controlled, in practice eliminating the need for outright electoral fraud, which could tarnish Putin's legitimacy. The state maintains de facto control of who is allowed to participate in elections. Navalny, for example, is barred from running for public office due to a court sentence for embezzlement passed earlier this year.

Ksenia Sobchak, a well-known television hostess and a leading oppositional voice since 2011, recently announced her intention to run for president in 2018. A 36year-old with five million Instagram followers, Sobchak could be a candidate for the disenchanted youth, who made up a significant portion of street protesters in spring and summer 2017. But many critics of the regime express disquiet about her candidacy, in part because she is the daughter of Putin's old boss from his days in St Petersburg. Regardless of the true motives behind Sobchak's decision, the ability to manipulate the election outcome, through the vetting of candidates, remains a formidable tool at Putin's disposal.

The regime also has control of the largest television stations, which remain the main source of information for the majority of the population. The dominance of television has been challenged by widening access to the internet in recent years - around 70 per cent are online - but the Russian internet is highly fragmented. While Navalny's most popular film about the Prime Minister Medved's corrupt activities has around 25 million hits on YouTube, the impact of online campaigning remains considerably less significant that the unified control of the traditional mass media by the state.

In addition, the president's team has a major financial advantage. The Putin campaign has a monopoly on state resources, as well as the ability to dissuade businesses from funding opponents of the regime. Regionally, state employees are under informal pressure to vote for Putin. All this makes the Russian vote technically free but not fair, more akin to a plebiscite on Putin's popularity than the election of a candidate from a choice of many.

\section{Longer term perspectives}

Russia is a relatively developed country with reasonable income levels $(\$ 9,000$ nominal Gross Domestic Product per capita). This compares favourably with immediate neighbours such as Ukraine $(\$ 2,000$ nominal GDP per capita), or the 
Central Asian republics from which Russia attracts significant numbers of economic migrants. Russia is an urbanised country, with one of the highest levels of literacy and higher education in the world. Its centres such as Moscow, St Petersburg or Kazan boast living standards comparable to many EU countries. At the same time, Russia has one of highest wealth inequality rates in the world with the richest tenth owning 87 per cent of the country's wealth. Its economic development is very uneven with significant disparity between different regions, and wealth concentrated in a few urban centres.

Corruption remains a persistent problem. Transparency International's Corruption Perception Index places Russia 131st of 176 countries. In addition to enormous economic waste, corruption feeds resentment and distrust of the political system. It is no accident that Alexey Navalny, the leading critic of Putin's regime, first emerged as an anti-corruption activist.

President Putin has tried to seize the anti-corruption agenda, and over the years Russia has witnessed a number of high profile corruption cases, mostly notably the Minister of Defence Anatoly Serdyukov's dismissal in 2012. Currently, the former minister of economic development Alexey Ulyukaev is standing trial for an alleged bribe extortion from Igor Sechin, a powerful head of the Rosneft oil giant, although it is often hard to distinguish cases like this from score settling among competing clans in the elite.

Given the nature of Russian neopatrimonial politics, with Putin's reliance on clientpatron politics that rewards loyalty above all else, battling high level corruption in any fundamental way may be incompatible with the survival of the regime itself. However, the need to spare resources in an economic downturn makes the need to promote able managers more acute, and some of Putin's old allies known for their lavish lifestyles with little to show for their managerial efficiency, have been dismissed from their lucrative jobs, such as Vladimir Yakunin, former head of Russian Railways.

There is an overall consensus that economic reforms are necessary if Russia is to achieve sufficient growth to lift real incomes and maintain its status as a significant international player. Although liberal economists are still mostly in charge of the economy, their influence has diminished. The decision to prioritise 
modernising the Russian military prompted the powerful finance minister Alexey Kudrin to resign in 2012. This hawkish trend was further boosted by the Ukraine crisis and Russia's involvement in Syria.

With Kudrin back in charge of preparing Putin's economic programme for the 2018 election, the economic 'guns or butter' debate is still ongoing in Russia. However, it is unclear if the current leadership is actually able to implement substantial reforms for the same reason it cannot fight corruption. A more likely scenario is that Russia will continue to muddle through with mediocre growth while hoping for a rebound in oil prices. The economy is predicted to grow by 1.7 per cent in 2017 after contracting by 3.1 per cent in 2015-16.

The main danger for the preservation of the current political system is another prolonged economic shock which could spark more protest. Russia already witnessed a spike in discontent, including about economic issues such as the introduction of road tariffs for heavy goods vehicles, as well as more politically orientated protests by the young urban middle class. The key is whether the two can ever merge into a unified protest movement with a single leader and a clear political agenda. The authorities will always have good opportunity to split such opposition by offering concessions to some groups, and isolating others. A natural barrier of distrust between representatives of different socioeconomic groups, such as truck drivers and the urban middle class, also undermine its cohesion. In addition, in contrast to 1917 or the late 1980s, when socialism and Western-style liberalisation respectively were seen as almost magical solutions, there is no consensus on the formula for change today. Russia's current zeitgeist in the form of great power nationalism is completely appropriated by Putin.

A successful presidential election, implementing a modicum of economic reforms, and succession planning will be the priorities for Putin's next term. He has already embarked on the policy of promoting a new generation of politicians, having made a series of gubernatorial and ministerial appointments of promising individuals in their 30s and 40s. Some of them, such as the Tula governor Aleksei Dyumin (b. 1972), the president's former bodyguard, are very close to Putin, and could take over from him in the 2020s, while still relying on Putin as their mentor in a style reminiscent of Deng Xiaoping's leadership in China. 


\section{Foreign policy}

The broad framework for understanding Russia's current standoff with the West lies in its failure to successfully integrate with Western political, social and economic structures. This was a key aim of the early post-Soviet Russia, but it ended by the mid2000s.

Instead, Russia increasingly began to define itself through resistance to Western hegemony. This change can be partly explained by the failure of domestic economic and political reforms in the 1990s, leading to a backlash against the Westernising zeal in the 2000s. Russian frustrations were also heightened by the West's failure to treat her as an equal after the end of the Cold War. Russia's insecurity, occasioned by the loss of superpower status and feeding on historical memories of conflict with Western powers in WWII and before, was particularly sensitive to the continuing eastward expansion of NATO, which by definition excluded Russia as a non-member.

Russia's main aim has been to limit a Western presence in the ex-Soviet space, except the Baltic states. This is seen by the Russian leadership as crucial for its security and long-term development. As the Ukraine crisis has shown, Russia's means of asserting its interest includes use of military force, seen as a way to compensate for its chronic economic and technological backwardness compared with the West.

By 2017, Russia has gone full circle in its foreign policy, from a rapprochement of equals with the West under Gorbachev during Perestroika, to attempts to integrate into the West under early Yeltsin, to efforts to form a partnership under early Putin, particularly in the aftermath of 9/11 attacks, and finally to a zero sum standoff after the 2008 war with Georgia, which became its fundamental strategy post the 2014 crisis in Ukraine.

As viewed from the Kremlin, Russia achieved maximum results in a hostile world dominated by much stronger rivals. However, the long term implications of Russia's assertive behaviour in Ukraine and Syria are still to become apparent.

The Ukraine crisis led to the seizure of the strategic asset of Crimea, but destroyed Russia's relations with its biggest and closest neighbour, Ukraine, while 
also alienating Russia from the West. Russia's attempts to replace the EU with China has not been successful enough in terms of trade but politically this move has proved useful. Engagement in Syria allowed Russia to reclaim its status as a global, rather than regional, great power, but a permanent engagement in the Middle East might prove too costly in the long term.

Having punched above its weight internationally, the Kremlin's priority for the next several years will be to consolidate the gains, such as its presence in Syria and Crimea, and to attempt a partial normalisation of relations with the West, provided it does not compromise its key national interests of maintaining its status as an independent power.

Relations with the US seem to be beyond repair for the foreseeable future in the aftermath of the 2016 US presidential elections. Mending relations with the EU will be more of a priority, particularly in the economic sphere. However, domestic economic reforms and boosting its connection with non-Western countries, above all China, will be at the top of Moscow's concerns. Whether the current leadership has the time and ability to implement the necessary reforms remains to be seen.

Will Russia have another revolution, or continue with its current evolution, which increasingly looks like stagnation? Probably the latter, simply because the majority of the Russians already lived through the experience of the major upheaval during Perestroika and post-Soviet transition. But the longer necessary changes are delayed, the higher the chance of a violent, sudden transformation in Russian affairs. 